\title{
A POTÊNCIA E ATUALIDADE DA OBRA PEDAGOGIA DO OPRIMIDO FRENTE A ATUAL ONDA NEOCONSERVADORA
}

\author{
THE POWER AND CURRENTNESS IN THE WORK OF PEDAGOGY OF THE \\ OPPRESSED FACING THE NEW NEOCONSERVATIVE WAVE
}

\author{
Valdo Barcelos \\ Doutor em Educação \\ Universidade Federal de Santa Maria - UFSM. \\ Santa Maria, RS - Brasil. \\ vbarcelos@terra.com.br \\ Maria Aparecida Azzolin \\ Doutora em Educação \\ Secretaria do Estado do Rio Grande do Sul - SEDUC/RS \\ Santa Maria, RS - Brasil. \\ cidaazzolin@gmail.com
}

Resumo: Este texto tem como objetivo refletir sobre a potência da obra freireana em geral e, em particular, sobre a atualidade do Pedagogia do Oprimido como forma de enfrentar a onda Neoconservadora que se abate sobre o mundo e o Brasil. Essa Onda Neoconservadora tem raízes fortemente presas ao pensamento fascista. Certamente que nem todo pensamento nacionalista/ultranacionalista desemboca, em regimes fascistas. Contudo, há que se estar atento, pois, de uma política nacionalista para a construção de um estado fascista podemos estar apenas a um passo. Assim que todas as pessoas e instituições que têm apreço pela democracia precisam estar atentos aos sinais de exacerbação de ideologias e de práticas que incentivem ultranacionalismos. De outra forma, há que entendermos que o fascismo não tem apenas um único rosto. Ao contrário, ele pode se apresentar com várias peles diferentes. Essa constatação, contudo, não deve servir para nos desesperançar. Ao contrário, deve ser um estímulo no sentido de nos inquietar, de nos fazer refletir sobre a realidade brasileira e, assim, nos movimentar na direção de uma educação que seja mais parecida com a cara miscigenada das gentes de Pindorama. Aos que bradam a expulsão de Freire e de suas ideias, de nossas escolas e universidades, devemos responder com mais propostas freireanas e não com menos. Se tivéssemos conseguido fazer Freire e seu legado mais encarnados em nossa educação, com certeza, certos ressurgimentos obscurantistas teriam muito mais dificuldades de renascer das cinzas de um passado de autoritarismos de triste lembrança.

Palavras-chave: educação e ultranacionalismo; onda neoconservadora; pedagogia do oprimido.

\begin{abstract}
This text has as its goal to reflect on the power of Freire's work in general and, in particular, on the currentness of the Pedagogy of the Opressed as a way to face the Neo Conservative Wave that has strong roots on the fascist thought. Certainly not all nationalist/ultranationalist thought ends up in fascist regimes. However, one has to be watchful, because a nationalistic policy and the construction of a fascist state could be just one step separated from each other. In that sense, all people and institutions that have an appreciation for democracy need to be alert to the signs of exacerbation of practices and ideologies that encourage ultra-nationalistic regimes. On the other hand, one has to understand that fascism does not have only one face. On the opposite, it can present itself in many different skins. This confirmation, however, must not lead us to despair. On the opposite, it should stimulate the discomfort, to make us reflect on the Brazilian reality, and, in that sense, move us towards the direction of an education more similar to the mixed faces of the people of Pindorama. To those who cheer on the expulsion of Freire and his ideas of our schools and universities, we should answer with more Freire-inspired proposals, and not less. If we had been able to make Freire and his legacy more present in our education, a certain obscure revival would most definitely have a bigger difficulty to be reborn from the ashes of a sad-memoir, authoritarian past.
\end{abstract}

Keywords: education and ultranacionalisms; neoconservative wave; pedagogy of the oppressed.

Para citar - (ABNT NBR 6023:2018)

BARCELOS, Valdo; AZZOLIN, Maria Aparecida. A potência e atualidade da obra Pedagogia do Oprimido frente a atual onda neoconservadora. Eccos - Revista Científica, São Paulo, n. 59, p. 1-17, e12399, out./dez. 2021. Disponível em: https://doi.org/10.5585/eccos.n59.12399. 


\section{Ecos de um passado fascista}

Chegou a hora de deixarmos de lado nossas contendas e construirmos nossos baluartes brancos mais uma vez. Essa aliança com raças de fora não significa nada além de morte para nós. (CHARLES LINDBERGH, 1939).

É fácil perceber, na epígrafe acima, como alguns discursos xenófobos atuais que se referem ao tema das migrações, a situação de discriminação aos estrangeiros, aos perseguidos de toda sorte em função de opiniões políticas, religiosas, étnicas, censuras de várias ordens, refugiados ambientais, questões de gênero. Enfim, podemos constatar que estamos vivendo uma onda de retrocessos conservadores e mesmo xenofóbicos que se espalham pelo mundo afora.

Ao refletir sobre a Onda Neoconservadora que se abate sobre o mundo contemporâneo, o professor de filosofia da Universidade de Yale nos EEUU (EEUU) Jason Stanley ${ }^{1}$ é enfático ao alertar sobre os perigos que os regimes democráticos correm ao não atentarem para os discursos nascentes que defendem nacionalismos e xenofobismos, muito bem disfarçados em defesa das massas populares e dos valores morais garantidores da "Lei e da Ordem". Em seu mais recente livro intitulado Como Funciona o Fascismo - a política do "nós” e "eles” (2018), o autor apresenta uma série de exemplos históricos de como os discursos de orientação fascistas encontram abrigo em amplos setores políticos e em diferentes camadas da população.

Sobre esse discurso defensor da "Lei e da Ordem", o autor escreve um capítulo no referido livro, no qual faz menção ao mundialmente conhecido caso de condenação de 5 jovens negros, norte-americanos, acusados de terem estuprado uma mulher branca no Central Park de Nova York (1989). O caso foi exaustivamente explorado nos diferentes meios de comunicação com a intenção de demonstrar o caráter violento, selvagem dos jovens negros americanos. Não por acaso, o senhor Donald Trump foi um dos tantos que, à época, engrossou a fila dos defensores de penas máximas (execução) desses "malucos e desajustados" criminosos, jovens negros. Stanley (2018) denuncia em seu livro que esses jovens eram tratados pelos ultranacionalistas brancos, como seres incapazes de respeitar a "Lei e a Ordem" da sociedade branca e civilizada americana.

Felizmente, o caso foi esclarecido e ficou provado que os cinco jovens eram inocentes das acusações. As investigações comprovaram, também, curiosamente, que os principais acusadores sabiam que os jovens não eram culpados, contudo, na ausência da identificação dos

\footnotetext{
${ }^{1}$ Jason Stanley, também lecionou em Oxford, Michigan, Cornell e Ruters. Ganhou o Prêmio PROSE da Association of American Publischers e prêmio da American Philosophical Association pelos seus livros publicados. Colabora com Jornais como The New York Times, The Washington Post, The Boston Review e outros setores da imprensa.
} 
reais estupradores, os jovens negros eram uma excelente alternativa para "fazer justiça" e encerrar o caso, restabelecendo, assim, a Lei e a Ordem. A cidade de Nova York foi condenada a indenizar os cinco jovens pela injustiça causada. Absurdamente, no recente ano de 2016, em plena campanha de Donald Trump para presidente, o atual Procurador-Geral dos EEUU Jeff Sessions, fez rasgados elogios aos comentários feitos por Donald Trump, sobre o caso dos jovens negros de 1989, acusados injustamente de estupro.

Com apenas esse exemplo, pode-se aprender que o uso de certas formulações como "Lei e Ordem", defendidas por Jeff Sessions e Donald Trump, podem servir para declarar como culpados, pura e simplesmente, pessoas ou grupos que não se enquadram nos padrões prescritos pelos valores morais de uma determinada sociedade.

A Onda Neoconservadora que por ora se apresenta e intensifica, vem carregada de uma espécie de saudosismo extremamente conservador. Algo como uma volta a um passado mítico onde tudo era melhor e todos eram felizes. Diga-se que esse tipo de ideologia tem raízes muito fortemente presas ao pensamento fascista. Certamente que nem todo tipo de pensamento nacionalista ou ultranacionalista desemboca em regimes fascistas. Contudo, há que se estar atento, pois, de uma política nacionalista para a construção de um estado fascista podemos estar a pouco menos de um passo. De outra forma, há que entendermos que o fascismo não tem apenas uma única cara, um único rosto. Ao contrário, ele - o fascismo - pode se apresentar com várias peles diferentes. Algo, porém, tem se mostrado presente ao longo de gerações: fascismo é sempre fascismo. Vale deixar explícito que por fascismo entendemos, de forma simplificada nesse texto, todo e qualquer tipo de ultranacionalismo étnico, religioso, cultural ou político.

São vários os exemplos de nacionalismos de extrema direita ressurgentes pelo mundo. São exemplares os casos da Rússia de Wladimir Putin; da Polônia; da Índia, da Turquia; e o mais emblemático, em termos de grande repercussão mundial em função da importância global, citamos o caso dos EEUU, da era Donald Trump. Ao contrário do que pode parecer, rapidamente, um dos principais slogans da campanha vitoriosa de Trump à presidência dos EEUU não foi uma criação sua nem de seus marqueteiros políticos. Referimo-nos a expressão "América First" (Estados Unidos em primeiro lugar). Trump não inventou essa expressão. Buscou-a na década de 30 do século passado. Quem cunhou essa expressão foi Charles Lindbergh um ousado piloto norte-americano. O primeiro piloto de avião a cruzar o Atlântico em um voo solitário. Esse ídolo norte-americano foi um ferrenho defensor da não entrada dos EEUU na guerra contra a Alemanha nazista. É de autoria deste cidadão a epígrafe que usamos na introdução. Já nessa introdução queremos chamar a atenção para a frase "Brasil, acima de 
tudo!". Frase, essa, que se tornou um dos mais veiculados slogans da recente campanha do atual Presidente do Brasil o Senhor Jair Bolsonaro.

O período da década de 20/30 do século passado, foi também um momento em que as políticas de restrição aos imigrantes mais prosperaram nos EEUU. Não por acaso, o governo de Donald Trump, desde seus primeiros dias, tem se caracterizado por impor todo tipo de dificuldades e de restrições à entrada no país de imigrantes, bem como de perseguição aos que se encontram em busca de legalização de suas situações. Historicamente, a perseguição e o endurecimento das políticas de imigração têm servido como ponto de partida para atitudes fascistas através dos tempos, mesmo em países democráticos. Novamente recorremos ao exemplo recente de Donald Trump, que não poupou insultos e impropérios aos imigrantes que tentam chegar aos EEUU ${ }^{2}$. Tal posição faz parte da prática de buscar desqualificar, de desumanizar aqueles grupos que se encontram em situação de vulnerabilidade. Stanley (2018), cita os casos recentes e emblemáticos de Ruanda e Mianmar. Neste último caso, a população de origem muçulmana Rohingya, sofreu por cinco anos, talvez o que foi o maior e mais cruel exemplo de limpeza étnica depois da Segunda Guerra Mundial.

Pode-se dizer que Trump ressuscitou e atualizou a frase America first. Mas Donald Trump não se contentou com essa cópia, foi mais longe e também incorporou em seu bemsucedido discurso de campanha, e tenta fazê-lo em suas políticas xenofóbicas e ultranacionalistas, outra máxima da década de 30 do século passado nos EEUU: "Make America great Again" (Fazer dos EEUU um grande país novamente).

Abrimos outro parêntese para lembrar que, coincidentemente, outra frase que fez muito sucesso na recente campanha do atual presidente brasileiro foi "Fazer do Brasil novamente uma grande potência na América Latina...vamos mudar o destino do Brasil”.

Jason Stanley alerta em seu livro que, tristemente, a década de 20/30 do século passado foi à época em que, a hoje tida como a maior democracia do mundo ocidental, mais flertou com o fascismo. É justo nessa época que o senhor Donald Trump vai buscar inspiração ultranacionalista para seu governo. Governo que, ao que tudo indica, tem sido uma referência ao recém-empossado Presidente do Brasil.

Outro baluarte para as políticas ultranacionalistas e fascistas é buscar apoio na ideia patriarcal de família. Uma família onde o provedor (sempre masculino) é o exemplo a ser seguido e obedecido. Toda e qualquer outra forma e tentativa de organização familiar, fora

\footnotetext{
${ }^{2}$ No momento em que estamos escrevendo esse texto está sendo travada mais uma batalha política entre o Sr. Donald Trump e os Democratas sobre a concessão de verba para a construção do famigerado muro entre Estados Unidos e México, promessa de campanha de Trump com o intuito de barrar a entrada de

imigrantes nos Estados Unidos da América.
} 
dessa ordem, nunca é bem-vista. Mais do que isso: é rechaçada como grande perigo às instituições. Junto ao medo fascista de misturar as etnias, o medo das formas de orientação e modos de viver a sexualidade, diferentes dos padrões da família patriarcal tradicional, se constitui em outro ponto de ataque dos ultranacionalistas. Assim fica mais fácil perceber e entender a rejeição, por exemplo, aos transgêneros, homossexuais, bem como a todo tipo de busca de viver a sexualidade fora dos padrões convencionados socialmente.

Acreditamos que a maneira mais adequada - talvez a única possível - de barrarmos as ideologias ultranacionalistas e de orientação fascistas é apostando, fortemente, na Democracia e na Liberdade. Para tanto, cabe explicitar que entendemos Democracia e Liberdade não como pontos de chegada, mas, sim, como pontos de partida. Toda vez que se atinge o ambiente democrático e de liberdade, constata-se que ele precisa ser ampliado. Pelo que se conhece das experiências democráticas, ao longo da história, é que elas nunca chegam a um final. Estão sempre sendo aperfeiçoadas. Outra questão importante a ser levada em conta é que Liberdade e Democracia não existem uma sem a outra. Só é possível uma sociedade democrática se os seus cidadãos viverem em liberdade. De outra forma, a liberdade só pode existir nas sociedades democráticas.

Uma conclusão imediata que se pode tirar dessa breve introdução é que tanto a Democracia quanto a Liberdade não têm limites. Pode-se perguntar, então: como assim, Liberdade e Democracia não têm limites? Como isso seria possível? Partimos do pressuposto de que Democracia e Liberdade são condições que não aceitam delimitações. Não se prestam a controles. Exigem, sim, pactos permanentes. Pactos que podem ser feitos e refeitos, porém, uma vez feitos, devem ser respeitados pelos participantes. São esses pactos, em especial sobre as responsabilidades de cada pessoa, bem como o respeito aos Direitos Humanos, que poderão garantir a longevidade dos sistemas democráticos.

De outra forma, toda vez que cedermos e aceitarmos colocar limites e imposições autoritárias, iremos contra os princípios que fundam essas duas conquistas generosas da humanidade - Democracia e Liberdade. Sobre esse tema da Democracia, e os desafios de preservá-la das ondas autoritárias, acaba de ser publicado nos EEUU um livro intitulado: How democracies die, em português: Como as Democracias Morrem, de autoria de Steven Levitsky e Daniel Ziblatt, ambos, professores da prestigiada universidade de Harvard. O livro acaba de ser lançado no Brasil no final do ano de 2018 pela Editora Zahar.

O livro é o resultado de 20 anos de pesquisas feitas pelos dois autores sobre a forma como muitas democracias acabaram se transformando em regimes autoritários. O mais revelador - e preocupante - é que vários desses regimes autoritários foram implantados, 
gradativamente, a partir de eleições legítimas de presidentes e dirigentes adeptos do autoritarismo e de ditaduras. Os autores citam exemplos como: Geórgia, Hungria, Nicarágua, Peru, Filipinas, Polônia, Rússia, Turquia e Ucrânia. Acrescentaríamos a situação dramática atual da vizinha Venezuela.

Em determinado momento do livro, os autores sugerem quatro perguntas simples que todo cidadão poderia fazer para testar se uma liderança política, ou um candidato em eleições democráticas apresenta tendências ao autoritarismo; cultiva ideias ultranacionalistas e/ou se mostra adepto de ideologias de orientação fascistizantes. São as seguintes as perguntas: (1) O candidato rejeita, em palavras ou atos, regras fundamentais da democracia?; (2) Põe em dúvida a legitimidade de seus oponentes?; (3) Tolera ou incentiva a violência política? e (4) Admite ou propõe restringir liberdades civis?

Os autores do livro fazem um importante alerta que julgamos estar muito adequado ao contexto de incertezas e de surgimento - ou ressurgimentos - de aventuras ultranacionalistas pelo mundo afora. Acreditamos que nós brasileiros(as), como qualquer cidadão, não estamos imunes a esses perigos. Os autores são enfáticos ao advertir que todos os setores da elite política, intelectual e empresarial, a imprensa democrática e livre, devem ficar atentos e jamais cair na tentação de sucumbir ao apelo, por vezes dissimulado e revestido de um bem articulado discurso em nome do "povo" e da "nacionalidade", de abrir as portas do poder a um dirigente político que apresenta inclinações autoritárias. A crença de que após assumir o poder esses dirigentes poderão ser contidos pode ser um engano difícil - talvez impossível - de ser reparado. Levitsky e Ziblatt (2018, p.56) advertem que "Construir instituições fortes leva décadas, e uma escorregada pode ter graves consequências a médio e longo prazo”. A construção da Democracia pode levar décadas, no entanto, pode ser destruída em um piscar de olhos ou, paradoxalmente, com alguns milhares de votos.

Damos uma pausa nessa breve contextualização sobre a Onda Neoconservadora mundial e nos ocuparemos, daqui em diante, ao momento atual brasileiro que, salvo melhor juízo, vive um processo muito semelhante quanto ao surgimento de uma onda Neo Conservadora que tentamos narrar nessa breve introdução.

Nossa ênfase, nesse texto, será sobre a repercussão dessa Onda Neoconservadora sobre a educação brasileira e como podemos entendê-la para apresentarmos alternativas a ela. Faremos isso tomando como principal referência à obra clássica intitulada Pedagogia do Oprimido (1968) de autoria de Paulo Freire (1921-1997). 


\section{Um homem, uma vida, um educador libertário}

A realidade não é assim, está assim. (Paulo Freire, O Grito Manso, 2003).

Em tempos de discursos como "escola sem partido"; de retornos obscurantistas do tipo combate a teorias científicas como Teoria da Evolução das Espécies, na escola; de preconceito de gêneros; de negação do pensamento intelectual crítico; de discursos de expurgo das ideias freireanas das escolas e universidades brasileiras, nada mais oportuno, e urgente, que promovermos uma profunda reflexão, lúcida e generosa, sobre o que queremos para a educação brasileira. Ou quem sabe reafirmarmos a desafiadora pergunta já feita pelo antropólogo e pensador brasileiro Darcy Ribeiro (1976) sobre se a educação brasileira estaria mesmo servindo às gentes do Brasil?

Acreditamos que temos na produção intelectual e acadêmica brasileira um acúmulo considerável de conhecimentos e de saberes que nos permitem estabelecer um fecundo diálogo, sobre educação e democracia, com todos e todas as pessoas e setores democráticos desse país que estejam dispostos a fazê-lo. Afinal, quantas outras nações do mundo moderno podem se orgulhar de ter em sua história um educador de espírito democrático e libertário como Paulo Reglus Neves Freire? Pensamos que esse fato, ao mesmo tempo em que nos enche de orgulho, nos exige uma imensa dose de responsabilidade com o legado desse educador. Um legado que, se levado em conta seriamente, poderá nos ajudar a saldar a vergonhosa dívida que toda sociedade brasileira tem com o imenso contingente de brasileiros e brasileiras que em pleno Século 21 ainda não conquistaram aquilo que Freire denominava da boniteza de aprender a ler e a escrever.

Não nos esqueçamos de que vivemos em um país onde cerca de oitenta por cento das crianças que moram nas periferias das médias e grandes cidades, que cursam o segundo ano do ensino fundamental, têm mais escolaridade que os pais. Importante lembrar o alerta feito por uma referência nos estudos e no trabalho com as proposições freireanas, o educador popular Carlos Rodrigues Brandão, quando este chama a atenção para o fato de que temos teorias demais, pedagogias demais, investigações demais, psicologias demais sobre educação escolar e, infelizmente, ações e atitudes de menos. Para esse educador, os modelos educacionais que têm sido adotados no Brasil, via de regra, têm carecido de algo elementar: das crianças reais e do país real em que vivemos: o Brasil (BRANDÃO, 2002). Outro estudioso da obra freireana José Eustáquio Romão é enfático ao reafirmar que "Quando se esquece dos processos culturais dos dominados é porque se quer evitar a transformação econômica, política e epistemológica e, 
lamentavelmente, a escola tem sido o instrumento dessa conservação. Todo conservadorismo funda-se na amnésia histórica" (ROMÃO, 2005, p.132).

O educador Paulo Reglus Neves Freire (1921-1997), nasceu na cidade do Recife no dia 19 de setembro do ano de 1921. Filho de Joaquim Temístocles Freire, capitão da Polícia Militar do Estado de Pernambuco e de Edeltrudes Neves Freire, carinhosamente, chamada de Tudinha. Freire teve uma irmã de nome Stela que foi professora primária e dois irmãos: Armando e Temístocles. Freire sempre foi muito grato aos seus irmãos homens que, em função das condições econômicas precárias da família, não concluíram seus estudos básicos, pois muito cedo tiveram que começar a trabalhar para ajudar financeiramente a família. Freire pode estudar graças a ajuda de seus irmãos.

Freire casou-se duas vezes. A primeira esposa chamava-se Elza Freire (1944-1986) com quem teve cinco filhos. A segunda esposa foi Ana Maria Araújo (Nita Freire). No ano de 1943, Freire formou-se em Direito pela Universidade do Recife. Abandonou a carreira de advogado muito cedo por sentir que essa profissão não lhe traria felicidade em função da distância entre a Justiça e o Direito. Começou, então, a carreira de professor no ensino Médio, ensinando Língua Portuguesa. No ano de 1946, Freire foi convidado para o cargo de diretor do Departamento de Educação e Cultura do Serviço Social no Estado em Pernambuco. Foi a partir de então que começou seu trabalho com a alfabetização de jovens e adultos. Dedicou especial atenção ao trabalho com os mais pobres. Uma das consequências dessa decisão foi a dedicação à construção de uma proposta revolucionária de alfabetização de adultos pobres, em grande parte camponeses do interior do Nordeste brasileiro. Com sua proposta ou "método" de alfabetização foi capaz de alfabetizar 300 adultos cortadores(as) de cana-de-açúcar num curto período de 45 dias. O educador Paulo Freire acabou tornando-se uma referência e uma inspiração para muitas gerações de professores(as), no Brasil, na América Latina e no continente africano. Seu trabalho foi reconhecido nos cinco continentes. Recebeu o título de Doutor Honoris Causa nas maiores e mais prestigiadas universidades do mundo. Foram nada mais nada menos que 27 Títulos de Doutor Honoris Causa. Paulo Freire ganhou ainda prêmios como: Educação para a Paz (das Nações Unidas, 1986) e Educador dos Continentes (da Organização dos Estados Americanos, 1992).

Seu envolvimento com a alfabetização de adultos pobres, inevitavelmente, o levou a despertar desconfiança num primeiro momento e muito ódio em seguida. Sua proposta política de educação ia de encontro às propostas das elites e dos governos da época. Tal contexto o levou a todo tipo de tentativa de difamação. Até de "traidor da pátria" foi chamado por muitos integrantes da elite rica do país. Teve importante militância política, fazendo parte da primeira 
diretoria executiva da Fundação Wilson Pinheiro. Foi Secretário de Educação (1989-1992) da Prefeitura da cidade de São Paulo na Gestão da prefeita Luiza Erundina. Com o golpe militar de 1964, Paulo Freire foi preso por 70 dias em um quartel do Exército em Recife. Durante esta prisão aconteceram fatos pitorescos e que Freire gostava de narrar em suas conferências como forma de não ficar amargurado em excesso com as adversidades pelas quais passou. Freire era um sujeito bem-humorado e que gostava de uma longa e calma conversa.

Paulo Freire morreu como viveu. Cheio de amorosidade, com sua gente e de indignação com as injustiças e "malvadezas" dos poderosos e dos tiranos. Semeou bonitezas por onde passou. Freire fez legítima a máxima do poeta mexicano Octávio Paz (1914-1998) quando esse afirmava que se "Morrestes de forma diferente daquela que viveu, é sinal de que não foi tua a vida que vivestes". Era a madrugada do dia 2 de maio de 1997, às cinco e meia da manhã, quando sua passagem foi registrada no leito hospitalar onde estava internado.

\section{Pedagogia do Oprimido - sonho, utopia e realidade}

Amigo, se você veio aqui pensando que ia ensinar nós a derrubar o pau, nós tem de dizer a você que não tem precisão. Nós já sabe derrubar o pau. O que nós quer saber é se você vai tá com nós na hora do tombo do pau. (Paulo Freire, Política e Educação, 2003)

Ao refletir sobre sua teoria da Ação Dialógica, no capítulo quarto do Pedagogia do Oprimido, Paulo Freire é enfático ao afirmar textualmente que: "Não há realidade histórica mais outra obviedade - que não seja humana" (FREIRE, 2016, p. 203). As razões que levam a essa compreensão seriam para Freire óbvias, pois, "Não há história sem homens, como não há uma história para os homens, mas uma história de homens que feita por eles, também se faz" (FREIRE, 2016, p. 204). Fica explícita, nessa formulação que, para Freire, homens e mulheres não são objetos da história ou objetos a serem pesquisados, estudados pelas elites. Freire é enfático sobre essa condição ao afirmar que: “O mundo não é um laboratório de anatomia nem os homens são cadáveres que devam ser estudados passivamente” (2016, p.208). Interpretamos essa formulação freireana como uma forma de colocar homens e mulheres não na periferia, mas, sim, no centro do fazer da História. Assim tomando o papel de homens e mulheres, na realidade em que vivem, podemos afirmar que homens e mulheres além de fazerem parte da História podem assumir seus destinos e fazerem, então, a História mesma. Com esta perspectiva filosófica e epistemológica de entendimento da existência de homens e mulheres no e com o mundo, Freire nos chama a atenção para o fato, às vezes esquecido por certa parcela das elites arrogantes, de que homens e mulheres não só fazem parte da História, mas sim, eles(as) são a própria História em permanente construção. 
É com essa assunção de seu papel de "fazedores e fazedoras" da História que homens e mulheres passam da condição de "homem-objeto" para "homem-sujeito" apontados por Freire no Pedagogia do Oprimido. Esse papel de donos de sua história é tão fundamental na obra freireana em geral, e, particularmente, na Pedagogia do Oprimido, que o educador faz questão de alertar, inclusive, para o risco de mesmo defensores de movimentos revolucionários tomarem os setores oprimidos como seus objetos de ação política. Sobre isso, em Pedagogia do Oprimido, Freire é radical e alerta que "O humanista científico revolucionário não pode, em nome da revolução, ter nos oprimidos objetos passivos de sua análise, da qual decorrem prescrições que eles devam seguir" (FREIRE, 2016, p.208). A maneira de evitar esse equívoco histórico e político é a liderança revolucionária, científico e humanista evitar repetir a prática das elites dominadoras de levar às últimas consequências a ideia de ignorância das massas populares. Setores progressistas não podem, jamais, "Crer nesse mito. Não tem sequer o direito de duvidar, por um momento, de que isto é um mito" (FREIRE, 2016, p. 209).

Freire dedica uma longa reflexão sobre essa possibilidade em Pedagogia do Oprimido, certamente por temer a manipulação de suas "gentes" por parte de oportunistas manipulares que acreditam que os fins justificam os meios. Vamos a mais uma manifestação de Freire sobre essa questão fundamental. Para ele, nenhuma liderança pode admitir,

Que só ela sabe e que só ela pode saber - o que seria descrer das massas populares.
Ainda quando seja legítimo reconhecer-se em um nível de saber revolucionário, em
função de sua mesma consciência revolucionária, diferente do nível de conhecimento
ingênuo das massas, não pode sobrepor-se a este, com o seu saber (FREIRE, 2016,
p.210).

Em nosso entendimento, tal preocupação de Freire é de uma atualidade inquestionável. Como outras questões levantadas por Freire, no Pedagogia do Oprimido, bem como de aresto em toda sua vasta obra, essa forma de interpretar a relação entre intelectuais e as classes populares ainda se manifesta em alguns setores das elites intelectuais e mesmo acadêmicas na sociedade brasileira. No Pedagogia do Oprimido (1968), Freire apresenta como uma de suas preocupações centrais a necessidade de educadores e educadoras respeitarem, reconhecerem e, assim, acolherem sincera e generosamente os saberes e os modos de vida de educandos e educandas, ou seja: reconhecerem o papel central dos e das aprendentes no processo educativo libertário e democrático. Ou isto acontece ou não avançaremos de um discurso demagogo sobre os setores populares, para uma real e concreta prática pedagógica emancipatória.

Percebemos nessa formulação epistemológica de Paulo Freire mais uma demonstração de sua lucidez política e de sua capacidade de análise, já a época, dos desfechos de embates no continente latino-americano, e mesmo no mundo, entre setores progressistas e setores 
reacionários autoritários. Freire traduz essa sua visão sobre o processo de libertação quando afirma textualmente que "Ninguém liberta ninguém, ninguém se liberta sozinho: os homens se libertam em comunhão" (FREIRE, 2016, p. 95). A libertação e a assunção da autonomia daqueles e daquelas que se encontram em condição de subjugação não pode ser vista como uma libertação que vem de outro - o libertador - como algo que vem de fora. Para Freire, essa libertação precisa ser entendida como uma libertação de pessoas - sujeitos de sua história - pois, não podemos nos esquecer, nunca, que em educação estamos lidando com homens e com mulheres no mundo. Como descrevia Freire, lidamos com gente. Nas suas palavras: "Estamos lidando com homens e não com coisas. Por isso, se não é autolibertação - ninguém se liberta sozinho -, também não é libertação de uns feita por outros. Não se pode realizar com os homens pela "metade". E, quando o tentamos, realizamos a sua deformação" (FREIRE, 2016, p. 97).

Talvez em poucos períodos da História brasileira se tenha vivido um momento em que tantos se jactaram a dizer o que deve ser feito para que o Brasil "descubra o seu destino", um destino de grande nação entre as demais nações no continente latino-americano. Um tal discurso, em nome da sociedade, na maioria das vezes tem como objetivo real esconder um traço de soberba elitista e de autoritarismo ideológico e político. Esse tipo de discurso "sobre" é denunciado por Freire no Pedagogia do Oprimido, pois, segundo o autor, homens e mulheres aprendem a partir de seu saber/fazer cultural, a partir de sua condição social e histórica como homem, mulher, pobre, branco, negro ou indígena.

Essa proposição freireana, é de uma simplicidade e ao mesmo tempo de uma profundidade e generosidade tão grandes que, talvez, seja difícil de ser entendida por setores reacionários e elitistas da sociedade de dominação e de opressão.

A alternativa de ação pedagógica mais adequada para não se cair nessa armadilha de transformar o ato libertador em mais um processo de "enganação" e não de verdadeira libertação é, para Freire, o caminho do diálogo. Diálogo, esse, que só se realizará, realmente, se corporificarmos nossas palavras pelos nossos exemplos e atitudes. A opção pela busca de sua libertação deve ser uma opção consciente feita por homens e por mulheres no exercício de sua autonomia e não uma dádiva, uma doação trazida por um "iluminado". Nesse sentido, a libertação proposta por Freire não é uma "Doação que lhes faça a liderança revolucionária, mas resultado de sua conscientização" (2016, p. 99). Isso pode parecer uma obviedade, contudo nem sempre é percebida pelas lideranças políticas, mesmo em alguns casos a própria liderança dita revolucionária se equivoca e acaba exercendo um papel político de doutrinadora e de porta voz dos seguimentos populares. Para Paulo Freire, são as próprias camadas oprimidas e populares que precisam perceber por sua própria reflexão - e aí sim fazer sua opção consciente - a 
possibilidade de sua inserção na realidade vivida e, a partir dessa constatação perceber que essa realidade pode, sim, ser por ele transformada. Freire sintetiza essa condição de necessidade com a seguinte formulação: “La realidad no es a si, está a si” (FREIRE: 2003, p.53).

Com essa perspectiva epistemológica e prática pedagógica proposta por Freire, estarse-ia dando um importante e decisivo passo na direção da passagem da realidade vivida para a realidade sonhada. Como na epígrafe, que colocamos no início desse item, mais que a pretensão de "ensinar" ao outro - coisas que às vezes ele já sabe e não sabemos que ele sabe - há que se estar junto a ele nas horas da "precisão". Como na fala do pequeno agricultor citado acima. Esse estar junto, na realidade vivida leva educando(a) e educador(a) a serem parceiros em uma tarefa cooperativa. Nesse processo de estar junto, e cooperar, se encontram dois sujeitos e não um sujeito e um objeto. Em tal tipo de processo acontece aquilo que Freire busca em toda sua obra, e em especial no Pedagogia do Oprimido: sujeitos "cointencionados à realidade, se encontram numa tarefa em que ambos são sujeitos no ato, não só de desvelá-la e, assim, criticamente conhecê-la, mas, também, no ato solidário de recriar juntos este conhecimento" (FREIRE, 2016, p.101). Ao agirmos com essa premissa pedagógica, solidária e libertária, estaríamos levando em consideração o que propõe Freire quando adverte que o papel do educador e educadora, realmente comprometidos com a autonomia e com a libertação de educandos e educandas, é reconhecer suas limitações não como incapacidades, mas, sim, como momentos de sua história no mundo em que vive. Nas palavras de Freire,

\footnotetext{
Una de las buenas qualidades de un professor, de una professora, es darles testimonio a lós alumnos de que la ignorância es el punto de partida de La sabiduria, que equivocar-se no es un pecado, sino que forma parte del proceso de conocer y que el error es un momento de La búsqueda del saber (FREIRE, 2003, p.54).
}

Ao partilharem essa ação homens e mulheres "Alcançam, na reflexão e na ação em comum, este saber da realidade, se descobrem como seus refazedores permanentes" (FREIRE, 2003, p.101).

Atreveríamo-nos apenas a acrescentar: homens e mulheres fazedores(as) e refazedores(as) de sonhos e realizadores(as) de utopias. Artífices de seus "inéditos-viáveis", transformando a realidade que está assim, em uma realidade outra: uma realidade antes ousada ser sonhada e, em função disso, possível de ser realizada. 


\section{Da espera vã ao esperançar que liberta}

No hay nada que esté fatalmente determinado en el mundo de La cultura...no hay fatalismo en la conducta humana...Hay que pelear. (FREIRE-Grito Manso-Argentina, 2003, p.78).

Paulo Freire começa sua importante obra intitulada Pedagogia da Esperança - um reencontro com a Pedagogia do Oprimido (1992), descrevendo a forma assombrada como algumas pessoas se manifestavam em relação ao título do referido livro. Eram alguns colegas seus de universidade e até parceiros de engajamento na busca de uma educação libertadora. Poucos conseguiam entender como alguém ainda se atrevia a falar em esperança frente uma conjuntura educacional tão adversa, especialmente para os seguimentos populares do país. Freire relata, bem-humorado, que um colega seu de universidade assim manifestou sua surpresa: "Mas como, Paulo, uma Pedagogia da Esperança no bojo de uma tal sem-vergonhice como a que nos asfixia hoje, no Brasil?" (FREIRE, 1992, p.09).

Uma das características que marcaram o educador Paulo Freire foi seu sempre encantamento com a educação brasileira. E esse encantamento se manifestava mesmo nas horas mais difíceis. Diga-se, que é nessas horas - difíceis - em que tudo parece desmoronar, que as alternativas parecem desaparecer, que a desesperança toma conta, que as pessoas raras e essenciais têm seu papel histórico e político mais importante.

Assim que, há que estarmos atentos aos ataques que a educação pública brasileira, em seus mais diferentes níveis, está sofrendo. É em momentos como esses que o legado de intelectuais como Paulo Freire são de fundamental importância. Contudo, não basta que brademos palavras de ordem e repitamos máximas históricas. Em momentos agudos se faz necessário, mais do que nunca, exercitarmos em nossa prática educacional cotidiana, teses como corporificação das palavras pelo exemplo ou a busca incessante do "inédito-viável". O momento atual em que os setores ultraconservadores chegaram ao poder central da nação, se faz necessária uma profunda reflexão, contemplando, inclusive a necessidade de buscar entender, intelectualmente, como chegou-se a essa situação de tão grave risco de retrocessos. Àqueles(as) que propõe o banimento das ideias freireanas das escolas e das universidades brasileira, há que responder com mais Paulo Freire. Não com uma leitura qualquer e apressada de suas obras, mas, sim, com um mergulho em seu conteúdo histórico, sociológico, político, libertário, filosófico e epistemológico, particularmente no campo da educação brasileira.

Precisamos ir além de dizermos da atualidade de Paulo Freire e de seu legado. O momento atual exige que revisitemos a obra freireana com olhos do presente. Que a olhemos com olhos livres e perspicazes. Certamente que muito do que foi escrito em 1968 será de maior 
valia se conseguirmos fazer o que o próprio Freire sempre sugeriu aos seus leitores, leitoras e seguidores(as): que não copiassem seu método, ou imitassem suas teses, mas, sim, que fizessem delas um ponto de partida, que as atualizassem sempre que as realidades mutantes assim o exigissem. Pensamos que não foi por mero acaso que o grande pensador brasileiro e profundo conhecer de Paulo Freire, o educador Ernani Maria Fiori (1914-1985) inicia o Prefácio de Pedagogia do Oprimido afirmando: "PAULO FREIRE É UM PENSADOR comprometido com a vida: não pensa ideias, pensa a existência" (FIORI, 1967, p.34).

Um pensador que, ao mesmo tempo em que vive o tempo presente, não descuida de atualizar o que já foi. Em Pedagogia do Oprimido Freire falou a partir de 1968, mas continua contemporâneo naquilo que é sua maior substância: a busca de uma educação libertadora de homens e de mulheres no tempo em que vivem suas existências. Assim visto, faz jus ao que escreveu Freire ao se referir ao seu Pedagogia do Oprimido, como um livro que não diz do que foi, mas, sim, um livro que está sendo.

Freire foi uma dessas pessoas raras. Freire representou, da melhor maneira possível, a condição de um intelectual na sociedade em que viveu. Intelectual no sentido mais poderoso e generoso dessa expressão: aquele que busca entender o mundo e o tempo em que vive e que tem o que dizer para diferentes gerações e mesmo diferentes culturas. Freire não se importava nem mesmo quando uns tantos faziam pouco ou o taxavam de ingênuo ao propor sonhos, ao defender utopias. Talvez, algo que ajudava a deixar seus críticos ainda mais desconcertados era a forma como Freire apresentava suas alternativas. O fazia com muita firmeza, porém, com uma ternura, uma boniteza que desarmava mesmo as mentes mais empedernidas, pelo menos em sua frente. Freire deixou marcas por onde passou. E não foram marcas quaisquer. Foram marcas profundas deixadas com doçura e com mansidão. Ele próprio mais de uma vez expressou que se considerava uma pessoa, um sujeito manso.

Freire nos deixou várias expressões muito fortes. Uma delas foi à do "Inédito Viável". Em Pedagogia da Esperança - um reencontro com a Pedagogia do Oprimido (duas décadas após o Pedagogia do Oprimido) Freire evoca a necessidade de retomar-se a ideia do inédito viável já proposta em Pedagogia do Oprimido, 20 anos atrás. Freire quis mostrar que aquilo que parece ser uma impossibilidade numa dada situação ou condição, pode ser mudada. Situações que se apresentam como imutáveis nem sempre o são. Haja vista o que já referenciamos anteriormente nesse texto, quando Freire sentencia: a realidade não é assim, está assim!

Mais que uma frase de efeito, essa, é, em verdade, um chamado a participação, um desafio ao esperançar feito por Freire. Esperançar como verbo, justamente para reafirmar a 
necessidade do pensar crítico, da ação, da não aceitação das situações, simplesmente, como se apresentam. Para Freire a existência humana se faz e refaz na esperança e no sonho. Freire não se cansava de reafirmar que sua esperança não era suficiente, mas, sim, necessária. Esse esperançar se faz ponto de partida para buscar realizar os sonhos, sem os quais, segundo Freire, não há existência humana. Freire deu uma importância muito grande para a proposição do "inédito-viável” 3 em sua obra. Não por acaso retoma essa proposição, cunhada no Pedagogia do Oprimido, vinte anos depois em Pedagogia da Esperança - um reencontro com a Pedagogia do Oprimido. Faz essa retomada como forma de demonstrar a atualidade de Pedagogia do Oprimido décadas depois. Atualidade, essa, que entendemos ainda muito presente, cinquenta anos depois.

Talvez em poucos outros momentos da História de nosso país tenhamos vivido uma época em que a necessidade de transformação, de esperanças, de necessidade de tanta criação e invenção tenha sido tão urgente como nos tempos atuais. Mais uma vez a atualidade de Pedagogia do Oprimido soa como um clamor, quando Freire escreveu: "Só existe saber na invenção, na reinvenção e na busca inquieta, impaciente, permanentemente, que os homens fazem no mundo, com o mundo e com os outros. Busca esperançosa também” (FREIRE, 2016, p.105). Freire deposita suas esperanças no(a) educando(a) mais que em qualquer outra possibilidade. Esperança nesses educandos e educandas sujeitos de sua história, contudo, isso só acontece quando os(as) educandos(as) se fazem realmente, "Educando quando e na medida em que conhece, ou vai conhecendo os conteúdos, os objetos cognoscíveis, e não na medida em que o educador vai depositando nele a descrição dos objetos, ou dos conteúdos" (FREIRE, 1992, p.47).

Nesse sentido, a esperança a que se refere Freire não é uma esperança vã, mas, sim, um compromisso com a história vivida pelas gentes do Brasil. Essa esperança se fundamenta na crença freireana de que homens e mulheres são seres "inconclusos" e, como tal, seres em permanente transformação de si e das suas realidades. Em função dessa condição, Freire toma os seres humanos como seres que "estão sendo", seres do inacabamento. Como alerta Freire, a História é uma construção inacabada, e tendo a História como uma construção radicalmente humana, a realidade também é uma construção permanente, portanto, inacabada. A educação num tal cenário é algo que está o tempo todo se refazendo. Nas palavras de Freire, a educação como "Um quefazer permanente. Permanentemente, na razão da inconclusão dos homens e do

\footnotetext{
Freire ao apresentar essa proposição do "inédito-viável" em Pedagogia do Oprimido, coloca que homens e mulheres se defrontam em sua existência com obstáculos e dificuldades. A essas dificuldades Freire denomina de "situações-limites". Segundo o educador, a ação frente a essas situações limites podem ser de aceitação, mas, também, de enfrentamento. As pessoas que optam pela segunda alternativa, são aquelas que vão em busca da realização de seus sonhos, da viabilização de suas utopias. É essa busca que poderá alcançar o que Freire denominou em Pedagogia do Oprimido de "inédito-viável".
} 
devenir da realidade... Dessa maneira a educação se refaz constantemente na práxis. Para ser tem que estar sendo" (FREIRE, 2016, p.127).

Esta é uma das diferenças fundamentais entre uma educação "Bancária" e uma educação libertadora. Enquanto a primeira busca a acomodação, a mesmice, a repetição dos conteúdos, a segunda deseja e busca ativamente a reflexão, a ação, a problematização das dificuldades, a superação das barreiras interpostas por uma dada realidade. A superação dessas dificuldades e barreiras é o primeiro passo para a superação dos limites e realização do "inédito-viável” que propõe Freire.

Quando nos encontramos com os colegas professores(as), tanto da Educação Básica quanto das universidades, ainda percebemos, tristemente, como se faz presente a opção - às vezes consciente outras inconscientes - de práticas educativas de uma educação bancária. Cinquenta anos após Pedagogia do Oprimido ser escrito e publicado, percebe-se como muitas de suas contribuições ainda se fazem ausentes em parte de situações reais, de nossas escolas reais, de nossos educandos e educandas reais.

Essa constatação, contudo, não deve servir para nos desesperançar. Ao contrário, deve ser um estímulo a mais no sentido de nos inquietar, de nos fazer refletir sobre a realidade brasileira e, assim, nos movimentar na direção de uma educação que seja mais parecida com a cara miscigenada das gentes do Brasil. Das gentes de Pindorama.

Aos que bradam a expulsão de Freire de nossas escolas e universidades devemos responder com mais propostas freireanas e não com menos. Ao contrário, se tivéssemos conseguido fazer Freire e seu legado mais encarnados em nossa educação, com certeza, certos ressurgimentos obscurantistas teriam muito mais dificuldades de renascer das cinzas de um passado de autoritarismos de triste lembrança.

Chegados a esse momento, desejamos vida longa a Pedagogia do Oprimido, em seus 50 anos de existência entre educadores(as) desse tão maltratado país. País onde a "Malvadeza" das elites reacionárias - como gostava de dizer Freire - insiste em produzir injustiças. Com esse sincero texto, que ora oferecemos aos possíveis leitores(as), não queremos muito, porém, queremos um pouco. Um pouco mais de diálogo sincero e generoso, um pouco menos de intolerância entre homens e mulheres, um pouco mais de esperança, muita alegria no fazer docente cotidiano e sempre mais generosidade entre as pessoas.

Para nos despedir de possíveis leitores(as), tomamos emprestado de Freire a última frase do Pedagogia do Oprimido, para dizer que: queremos um mundo onde seja um pouco "menos difícil AMAR". 


\section{Referências}

BRANDÃO, C.R. A Educação como Cultura. Campinas. Mercado das Letras, 2002.

FIORI, Ernani Maria. Prefácio. In: FREIRE, Paulo. Pedagogia do Oprimido. 60 ed. Rio de Janeiro: Paz e Terra, 2016.

FREIRE, P. Pedagogia do Oprimido. 60 ed. Rio de Janeiro. Paz e Terra, 2016.

FREIRE, P. Política e Educação. São Paulo. CORTEZ, 2003.

FREIRE, P. El grito manso. Buenos Aires. siglo veintiuno, 2003.

FREIRE, P. Educação como Prática da liberdade. Rio de Janeiro. Paz e Terra, 1992.

FREIRE, P. Pedagogia da Esperança - um reencontro com a Pedagogia do Oprimido. Rio de Janeiro. Paz e Terra, 1992.

LEVITSKY, S.; ZIBLAT, D. Como as Democracias morrem. Rio de Janeiro. ZAHAR Editores, 2018.

LINDBERGH, C. “Aviation, Geografy, and Race”. Reader's Digest. P.64-7, Nov. 1939.

PAZ, O. Laberinto de la soledad. Obras Completas. V. 8. México. Fondo de Cultura

RIBEIRO, D. O povo brasileiro - a formação e o sentido do Brasil. São Paulo. Companhia das Letras, 1996.

ROMÃO, J. E. Multiculturalidade na Educação. Revista Sociedade, Educação \& Culturas. N.23, 2005. (pg.125-135). Porto-Portugal.

STANLEY, J. Como funciona o fascismo - A Política do "nós" e "eles". Porto Alegre. L\&PM Editores, 2018. 